\title{
Does investing in sound corporate governance pay? A South African study
}

\author{
N. Mans-Kemp*, P.D. Erasmus and S. Viviers \\ Department of Business Management, Stellenbosch University, Private Bag X1, Matieland, 7602
}

*To whom all correspondence should be addressed

nadiamans@sun.ac.za

\begin{abstract}
Despite increased recognition of the importance of sound corporate governance practices in emerging markets, previous researchers reported inconclusive evidence on the association between corporate governance and financial performance. Authors that predominantly focused on board-related variables might, however, have failed to reflect the complex nature of corporate governance. The financial performance measures employed in the majority of previous studies also ignored the potential risk-reducing benefits that sound corporate governance could hold for emerging market firms. The purpose of this article was thus to investigate the relationship between a comprehensive measure of corporate governance and the riskadjusted performance of selected South African companies. A unique corporate governance database was compiled by conducting content analysis on the considered companies' annual reports over the period 2002 to 2010 . Aspects related to nine corporate governance categories were taken into account. In addition to the accounting and market-based performance measures that were employed in previous studies, South African companies' risk-adjusted performance was also taken into account. The capital asset pricing model and the Fama-French three-factor model were employed to estimate risk-adjusted abnormal returns for four corporate governance-sorted portfolios. Both estimations revealed that the portfolio comprising of companies with the highest corporate governance scores managed to significantly outperform the market.
\end{abstract}

\section{Introduction}

The German philosopher Arthur Schopenhauer (in Viviers, Bosch, Smit \& Buijs, 2009) stated that "there are three steps in the revelation of any truth: Firstly, it is ridiculed; secondly, it is resisted and thirdly, it is considered self-evident". This statement is particularly apt in light of the increasing number of responsible investors who actively integrate environmental, social and corporate governance (ESG) considerations into their investment analyses and ownership practices.

Some investors base their investment decisions on the moral conviction that the effective deployment of capital can (partly) address their ESG concerns. In addition to a moral case for ESG compliance, other investors are considering the potential to align ESG considerations with financial returns. Such investors are interested in the financial materiality (also called the business case) of responsible investing (Investment Leaders Group, 2014).

Many global and local investors regard ESG management to be narrowly concerned with corporate governance. They hence tend to place more focus on corporate governance than environmental and social considerations (Van der Ahee \& Schulschenk, 2013). This tendency might partly be ascribed to the publication of several corporate governance guidelines since the 1990s. Furthermore, while some corporate governance aspects (e.g. board composition) are relatively easy to measure, environmental and social aspects might be more difficult to appraise.
Corporate governance started to attract attention within an emerging market context in 1994 with the publication of the first King Report in South Africa. The country has a welldeveloped corporate governance framework that provides compliance guidance to board members, managers and accountants of locally listed firms. The King recommendations are, however, criticised by some local roleplayers for encouraging "tick-box" compliance practices (Heath, 2014). If a firm merely attempts to comply with the basic King recommendations, the benefits of effective corporate governance compliance might not be obtained. It is therefore essential to evaluate a firm's overall corporate governance position, rather than focusing only on the most visible aspects.

High compliance costs could also constrain firms from effectively implementing the King guidelines. Some investors might perceive corporate governance as an unnecessary expense that reduces their investee firms' ability to pursue profitable opportunities (Du Plessis, Hargovan \& Bagaric, 2011). These investors should, however, realise that the failure to implement corporate governance practices could expose them to risks that might result in lower investment returns over the long run.

While South Africa offers abundant investment opportunities, various ESG-related challenges such as HIV/AIDS, water scarcity and a lack of board diversity should not be ignored (Department: National Treasury Republic of South Africa, 2011). The existence of a positive association between corporate governance and risk-adjusted share returns might encourage more investors to invest in locally-listed companies with high corporate governance compliance. 
Extensive research has been conducted on the association between corporate governance and financial performance. Conflicting results were reported, reflecting positive, negative or no relationship between the considered variables. A possible reason for these inconsistent results is that researchers, especially in the emerging market context, typically applied one-dimensional (board-related) variables as a proxy for corporate governance. Such measures may be insufficient to reflect this concept's complex nature. Previous authors almost exclusively considered corporate governance disclosure and ignored the acceptability of firms' compliance practices. Furthermore, the majority of studies employed relatively simplistic accounting-based and non-risk adjusted market-based measures which failed to reflect the riskreducing potential of sound corporate governance compliance.

The primary objective of this article was thus to investigate the relationship between a comprehensive measure of corporate governance and the risk-adjusted performance of selected companies that were listed on the Johannesburg Stock Exchange (JSE) over the period 2002-2010. This time frame encompasses a period of high economic growth, a global financial crisis and the subsequent local recession. By conducting this study in South Africa, it is possible to investigate both disclosure and acceptability dimensions of corporate governance, given the well-developed framework provided by the King Reports. This article is the first local study that examines the association between corporate governance and performance by employing a comprehensive corporate governance measure and risk-adjusted returns over an extended period of time.

Given the absence of comprehensive and standardised corporate governance data for the considered time period, the study's first secondary objective was to compile a unique corporate governance database based on the content analysis of the considered firms' published annual reports. The second secondary objective was to assess the relationship between corporate governance and selected accounting and marketbased measures (which focus only on return and excludes risk) that were employed by previous researchers. The third secondary objective was to extend on previous studies by investigating the relationship between corporate governance and the risk-adjusted performance of the considered companies by employing both the capital asset pricing model (CAPM) and the Fama-French three-factor model.

The rest of the article is structured as follows: First, a discussion is provided on corporate governance as a criterion used by responsible investors. Thereafter, a summary of previous studies reporting on the relationship between corporate governance and financial performance are provided. The methodology is then described, followed by a discussion of the empirical findings. Finally, conclusions and recommendations, based on the identified limitations, are offered.

\section{Literature review and hypotheses development}

The most widely used definition of corporate governance is the "system by which companies are directed and controlled" (Committee on the Financial Aspects of Corporate Governance, 1992). Corporate governance can also be defined as the manner in which finance suppliers assure themselves of getting a return on their investment (Shleifer \& Vishny, 1997). The actions of managers and the implementation (or lack) of corporate governance mechanisms are likely to have an effect on a firm's investment, financing, distribution and operating decisions. The accountability of a company's managers to financial claimholders might be enhanced by having extensive corporate governance mechanisms in place. As a result, countries with efficient governance systems could also become preferred locations for companies to operate and invest in (Grandori, 2004).

South Africa is characterised by a well-developed corporate governance framework since the early 1990s. The King Report was revised in 2002, 2009 and 2016 to account for local statutory changes and global developments. The King Reports provide guidelines to JSE-listed firms regarding, inter alia, the role and responsibilities of directors, executive emolument and sustainability aspects.

In line with the "comply or explain" approach of the King II Report, the JSE Listing Requirements (JSE, 2005) oblige listed firms to disclose their compliance or explain noncompliance with the voluntary King II recommendations in their annual reports. This approach could, unfortunately, have resulted in "tick-box" compliance. In contrast, the King III Report follows an "apply or explain" approach that acknowledges that it is not a question of whether to comply or not, but rather to consider how the principles can be practically applied (Institute of Directors in Southern Africa (IoDSA), 2009).

South Africa's ESG-regulatory environment is rapidly evolving. In 2011, Regulation 28 of the Pensions Fund Act (No. 24 of 1956) was amended to promote the inclusion of ESG considerations in pension funds' investment analysis and ownership practices. Furthermore, the Code for Responsible Investing in South Africa (CRISA) was introduced in the same year to give guidance to institutional investors on how they should execute their investment analysis and ownership activities (IoDSA, 2011).

As mentioned in the introduction, responsible investors can base their investment decisions on a business case for corporate governance. A number of researchers considered this business case in emerging and developing markets and reported inconclusive evidence on the relationship between corporate governance and various performance measures. Table 1 provides a summary of selected previous studies. 
Table 1: Summary of corporate governance and financial performance studies

\begin{tabular}{|c|c|c|c|c|}
\hline Author(s) and year & $\begin{array}{l}\text { Country/ } \\
\text { Countries }\end{array}$ & $\begin{array}{l}\text { Corporate } \\
\text { governance } \\
\text { measure(s) }\end{array}$ & $\begin{array}{l}\text { Performance } \\
\text { measure(s) }\end{array}$ & Findings \\
\hline Klapper \& Love (2004) & $\begin{array}{l}14 \text { emerging markets } \\
\text { (including South } \\
\text { Africa) }\end{array}$ & $\begin{array}{l}\text { CLSA corporate } \\
\text { governance } \\
\text { questionnaire }\end{array}$ & $\begin{array}{l}\text { Return on Equity } \\
\text { (ROE); Tobin's Q }\end{array}$ & $\begin{array}{l}\text { Better corporate governance was correlated with better } \\
\text { operating performance and market valuation. }\end{array}$ \\
\hline $\begin{array}{l}\text { Haniffa \& Hudaib } \\
\text { (2006) }\end{array}$ & Malaysia & $\begin{array}{l}\text { Board-specific } \\
\text { characteristics; } \\
\text { shareholding }\end{array}$ & $\begin{array}{l}\text { Return on assets } \\
\text { (ROA); Tobin's Q }\end{array}$ & Positive relationships were reported. \\
\hline Abdo \& Fisher (2007) & South Africa & $\begin{array}{l}\text { Self-composed } \\
\text { governance index }\end{array}$ & $\begin{array}{l}\text { Total share return } \\
\text { (TSR); market-to-book } \\
\text { value; price/earnings }\end{array}$ & $\begin{array}{l}\text { Positive correlation between corporate governance and } \\
\text { share returns. }\end{array}$ \\
\hline $\begin{array}{l}\text { Kyereboah-Coleman } \\
\text { (2007) }\end{array}$ & $\begin{array}{l}\text { Sample of listed firms } \\
\text { from Ghana, Nigeria, } \\
\text { Kenya and South } \\
\text { Africa }\end{array}$ & Board variables & ROA; Tobin's Q & Mixed results were reported. \\
\hline Imam \& Malik (2007) & Bangladesh & Ownership structure & TSR; Tobin's Q & Positive relationships were noted. \\
\hline Kajola (2008) & Nigeria & Board characteristics & ROE & $\begin{array}{l}\text { Positive relationships were noted between ROE, board } \\
\text { size and CEO status respectively. }\end{array}$ \\
\hline Chi (2009) & Taiwan & $\begin{array}{l}\text { Transparency and } \\
\text { disclosure }\end{array}$ & Tobin's Q & $\begin{array}{l}\text { Performance is positively associated with disclosure } \\
\text { quality. }\end{array}$ \\
\hline Ehikioya (2009) & Nigeria & Board characteristics & $\begin{array}{l}\text { ROA; ROE; price- } \\
\text { earnings; Tobin's Q }\end{array}$ & $\begin{array}{l}\text { Negative associations were reported for performance, } \\
\text { CEO duality and family members on board respectively. }\end{array}$ \\
\hline $\begin{array}{l}\text { Morey, Gottesman, } \\
\text { Baker \& Godridge } \\
(2009)\end{array}$ & $\begin{array}{l}21 \text { emerging countries } \\
\text { (including South } \\
\text { Africa) }\end{array}$ & $\begin{array}{l}\text { AllianceBernstein } \\
\text { ratings }\end{array}$ & $\begin{array}{l}\text { Tobin's Q; price-to- } \\
\text { book ratio }\end{array}$ & $\begin{array}{l}\text { Corporate governance improvements resulted in positive } \\
\text { market valuations. }\end{array}$ \\
\hline $\begin{array}{l}\text { Ramdani \& Van } \\
\text { Witteloostuijn (2010) }\end{array}$ & $\begin{array}{l}\text { Indonesia, Malaysia, } \\
\text { South Korea and } \\
\text { Thailand }\end{array}$ & $\begin{array}{l}\text { Board independence; } \\
\text { CEO/chair role duality }\end{array}$ & ROA & $\begin{array}{l}\text { Relationship between corporate governance and firm } \\
\text { performance was different across the conditional } \\
\text { quantiles of the performance distribution. }\end{array}$ \\
\hline Othman (2012) & $\begin{array}{l}11 \text { emerging African } \\
\text { markets (including } \\
\text { South Africa) }\end{array}$ & $\begin{array}{l}\text { Board structure and } \\
\text { process disclosure } \\
\text { (BSPD) }\end{array}$ & $\begin{array}{l}\text { ROE; Tobin's Q; } \\
\text { market-to-book ratio }\end{array}$ & $\begin{array}{l}\text { Influence of BSPD on performance was more } \\
\text { pronounced for financial than non-financial Anglophone } \\
\text { African firms. }\end{array}$ \\
\hline $\begin{array}{l}\text { Alhaji, Yusoff \& } \\
\text { Alkali (2012) }\end{array}$ & Malaysia & $\begin{array}{l}\text { Board-specific } \\
\text { characteristics }\end{array}$ & $\begin{array}{l}\text { Earnings per share } \\
\text { (EPS) }\end{array}$ & No significant relationship was noted. \\
\hline $\begin{array}{l}\text { Fallatah \& Dickins } \\
(2012)\end{array}$ & Saudi Arabia & $\begin{array}{l}\text { Board aspects and } \\
\text { share ownership }\end{array}$ & $\begin{array}{l}\text { ROA; Tobin's Q; } \\
\text { market value of equity }\end{array}$ & $\begin{array}{l}\text { Corporate governance and ROA was unrelated; } \\
\text { corporate governance and Tobin's Q was positively } \\
\text { related. }\end{array}$ \\
\hline $\begin{array}{l}\text { Mollah, Al Farooque \& } \\
\text { Karim (2012) }\end{array}$ & Botswana & $\begin{array}{l}\text { Board-related } \\
\text { variables; ownership } \\
\text { structure }\end{array}$ & ROA; ROE; Tobin’s Q & No significant relationships were reported. \\
\hline $\begin{array}{l}\text { Ntim, Opong \& } \\
\text { Danbolt (2012) }\end{array}$ & South Africa & $\begin{array}{l}\text { Disclosure based on } 50 \\
\text { King II provisions }\end{array}$ & $\begin{array}{l}\text { TSR, ROA and Tobin's } \\
\text { Q }\end{array}$ & $\begin{array}{l}\text { Good corporate governance disclosure practices were } \\
\text { positively related to firm value. }\end{array}$ \\
\hline $\begin{array}{l}\text { Hassan \& Halbouni } \\
\text { (2013) }\end{array}$ & United Arab Emirates & $\begin{array}{l}\text { Voluntary disclosure; } \\
\text { board aspects; audit } \\
\text { type }\end{array}$ & ROA; ROE; Tobin’s Q & $\begin{array}{l}\text { Voluntary disclosure, CEO duality and board size } \\
\text { influenced accounting performance. }\end{array}$ \\
\hline Velnampy (2013) & Sri Lanka & $\begin{array}{l}\text { Board and committee } \\
\text { characteristics }\end{array}$ & ROA; ROE & Corporate governance did not affect profitability. \\
\hline Hörnmark (2015) & $\begin{array}{l}23 \text { emerging markets } \\
\text { (including South } \\
\text { Africa); results were } \\
\text { compared with USA }\end{array}$ & $\begin{array}{l}\text { MSCI ESG-portfolio; } \\
\text { corporate governance } \\
\text { score was mainly based } \\
\text { on board-related } \\
\text { aspects }\end{array}$ & $\begin{array}{l}\text { CAPM was used for } \\
\text { Brazil, Russia, India, } \\
\text { China and South Africa } \\
\text { (BRICs) countries; } \\
\text { Fama-French three- } \\
\text { factor model was } \\
\text { applied for other } \\
\text { countries }\end{array}$ & $\begin{array}{l}\text { Insignificant positive alpha was reported for the South } \\
\text { African portfolio. }\end{array}$ \\
\hline $\begin{array}{l}\text { Islam, Sathye \& Hu } \\
\text { (2015) }\end{array}$ & Bangladesh & $\begin{array}{l}\text { Corporate governance } \\
\text { compliance score } \\
\text { (based on } 99 \text { corporate } \\
\text { governance elements } \\
\text { applicable to banks) }\end{array}$ & $\begin{array}{l}\text { ROA; cost-to-income } \\
\text { ratio (efficiency impact } \\
\text { on performance) }\end{array}$ & $\begin{array}{l}\text { No significant relationship was found between } \\
\text { Bangladeshi banks' corporate governance practices and } \\
\text { financial performance. }\end{array}$ \\
\hline $\begin{array}{l}\text { Pamburai, Chamisa, } \\
\text { Abdulla \& Smith } \\
\text { (2015) }\end{array}$ & South Africa & Board-related variables & $\begin{array}{l}\text { Economic value added } \\
\text { (EVA); ROA; Tobin's } \\
\text { Q }\end{array}$ & $\begin{array}{l}\text { Board size was negatively related to EVA. A positive } \\
\text { relationship was reported between Tobin's Q and the } \\
\text { proportion of non-executive directors. A negative } \\
\text { association was noted between the frequency of board } \\
\text { meetings and ROA and Tobin's Q respectively. }\end{array}$ \\
\hline
\end{tabular}

Source: Authors' compilation

Perusal of Table 1 reveals that many researchers focused only on board-related aspects. This tendency is not surprising, given that the directorate is regarded as the focal point of corporate governance. Board-related variables are also easy to quantify. A lack of standardised corporate governance data could furthermore have limited the comprehensiveness of preceding studies.
Previous researchers seemed to favour accounting-based ratios (such as ROA) or relatively unsophisticated marketbased measures (such as TSR) when examining the relationship between corporate governance and financial performance. Inconclusive evidence was reported on the nature of this association. As far as could be determined, no previous researchers employed a multi-factor model to 
estimate risk-adjusted abnormal returns for portfolios that were compiled based on a comprehensive analysis of JSElisted firms' corporate governance compliance.

In light of the inconclusive evidence on the relationship between corporate governance and performance and to investigate whether the benefits of corporate governance compliance is perhaps reflected on a risk-adjusted basis, the following null hypotheses were formulated:

$H_{01}$ : There is no relationship between corporate governance and the ROA, ROE, EPS and TSR of selected JSE-listed companies.

$H_{02}$ : There is no relationship between corporate governance and the risk-adjusted abnormal returns of selected JSE-listed companies.

\section{Data collection}

Secondary data were collected for companies that were listed in six JSE industries. Firms that were listed in the consumer goods, consumer services, industrials, technology, telecommunications and health care industries over the period 2002 to 2010 were considered. Table 2 provides a summary of the considered companies.

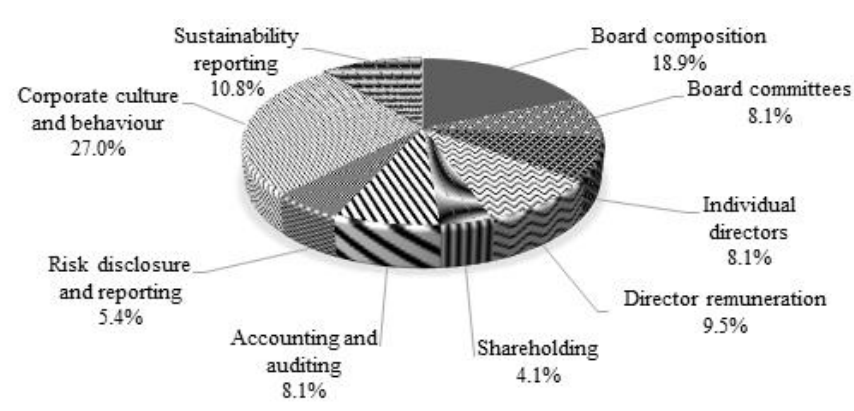

Figure 1: Contribution of the corporate governance categories to the total CGS ${ }^{\text {(a) }}$

(a) The 9 categories comprised 39 recommendations. Details could not be provided due to a confidentiality agreement.

Source: Researchers' compilation

Table 2: Summary of the considered companies (\% of total sample)

\begin{tabular}{|c|c|c|c|c|c|c|c|}
\hline Year & Health care & Consumer goods & Consumer services & Technology & Telecoms & Industrials & Total \\
\hline 2002 & 3.1 & 20.4 & 27.2 & 14.1 & 1.0 & 34.0 & 191 \\
\hline 2003 & 3.1 & 20.3 & 27.6 & 14.1 & 0.5 & 34.4 & 192 \\
\hline 2004 & 2.4 & 19.3 & 27.1 & 12.7 & 1.2 & 37.3 & 166 \\
\hline 2005 & 1.9 & 20.5 & 25.5 & 13.7 & 1.2 & 37.3 & 161 \\
\hline 2006 & 2.7 & 17.8 & 28.8 & 11.6 & 2.1 & 37.0 & 146 \\
\hline 2007 & 2.8 & 19.9 & 25.5 & 12.8 & 2.1 & 36.9 & 141 \\
\hline 2008 & 2.7 & 16.7 & 23.3 & 10.7 & 2.7 & 44.0 & 150 \\
\hline 2009 & 3.3 & 16.6 & 23.2 & 10.6 & 2.6 & 43.7 & 151 \\
\hline 2010 & 4.3 & 16.3 & 23.4 & 9.2 & 2.8 & 44.0 & 141 \\
\hline
\end{tabular}

Source: Authors' compilation

To ensure enough data points for analysis purposes, the selected firms had to be listed for at least two years during the research period. In an attempt to limit survivorship bias, companies that delisted during the research period were also considered. Firms that were listed in the financials, basic materials and oil and gas industries were excluded due to the differing nature of their financial reporting and extensive regulation. No firms were listed in the utilities industry during the research period.

Since standardised corporate governance data were not readily available for JSE-listed firms for the period under review, the researchers compiled a unique database. A comprehensive corporate governance score (CGS) was determined for each of the firms for every year that they were listed during the research period. A refined version of the Public Investment Corporation (PIC) Corporate Governance Rating Matrix was employed for this purpose. The Centre for Corporate Governance in Africa designed this matrix on behalf of the PIC, one of the largest investment managers on the African continent. The comprehensive CGS employed in this study was deemed superior to the predominantly onedimensional (board-related) measures used in the majority of previous studies (refer to Table 1). The refined instrument consisted of nine categories, as illustrated in Figure 1.

The research period ranged from 2002 (the year that the King II Report became effective) to 2010. This report's recommendations were thus applicable to JSE-listed firms for almost a decade. Although the King III Report came into effect on 1 March 2010, integrated reporting only became mandatory for all JSE-listed companies in 2011 (Global Sustainable Investment Alliance, 2012). Depending on a firm's financial year end (before or after 1 March 2010), some JSE-listed companies hence only started to comply with the King III guidelines after their 2010 financial year end. Many firms with a financial year end after 1 March 2010 furthermore aimed to comply with the King II guidelines for 
the largest part of their 2010 financial year. For consistency sake, the recommendations of the King II Report were therefore applied for the entire period. The considered companies' annual reports were sourced from INET BFA (currently known as IRESS).

A list of key words was compiled for each category, based on the King II Report and applicable literature. These key words were used to conduct content analysis on the considered firms' annual reports. The reported corporate governance aspects were coded based on two dimensions, namely disclosure and acceptability. The focus of the disclosure dimension was on whether information related to the category under consideration was indicated/not indicated in an annual report. If evidence of information on a specific category was found, it was coded 1 . The acceptability criteria centred on whether the disclosed aspect was in line with selected King II recommendations. If the disclosed aspect was deemed acceptable, it was coded 1 ; otherwise it was coded 0 .

Annual CGSs were compiled for 230 companies (1 439 observations). The maximum CGS of 74 encompassed a maximum score of 39 for disclosure and 35 for acceptability. Acceptability criteria were not set for four corporate governance aspects (gender and race diversity, executive director remuneration and shareholding), since clear guidelines could not be determined. Care was taken to ensure that the coding was applied in the same manner for all the companies.

In line with previous researchers (refer to Table 1), the ROA, ROE and EPS accounting-based measures were employed. Proponents of these ratios argue that profitability ratios are less influenced by the speculative behaviour of investors than market-based measures (Joh, 2003). A possible drawback is that reported profit could be manipulated by managers, resulting in inaccurate accounting ratios. Proponents of market-based measures reason that these measures are less subject to managerial manipulation in well-regulated markets than accounting-based measures (Mulsow, 2011). The TSR measure (which does not reflect risk) was hence also employed. Dybvig and Warachka (2010) indicated that the relationship between Tobin's Q and firm performance is confounded by endogeneity. Based on their critique, this ratio was not considered.

In addition, risk-adjusted abnormal returns were also estimated. Although the single-factor CAPM is commonly used to estimate risk-adjusted returns for South African firms, this model is not necessarily adequate (Ward \& Muller, 2012). Fama and French (1992) indicated that returns are not only based on market risk, but also on the spread in returns between small and large firms and value and growth shares respectively. Both the CAPM and Fama-French three-factor models were therefore used to make provision for risk and to control for the possibility that managers with poor compliance could inflate the other selected performance measures by engaging in risky activities. The following equations were used:
Annual return on assets (ROA) ${ }^{(a)}$ :

$\frac{\text { Profit before interest and tax }- \text { total profits of extraordinary nature }- \text { taxation }}{\text { Total assets }} \times 100$

Annual return on equity (ROE) ${ }^{(a)}$

Profit after tax

Ordinary share capital + distributable reserves $+\quad \times 100$

non-distributable reserves + preference share capital + non-controlling interest

Annual headline earnings per share (EPS) ${ }^{\text {(a) }}$

Profit or loss attributable to ordinary shareholders of the parent firm* Weighted average number of ordinary shares issued

*Separately identifiable re-measurements (net of related tax and non-controlling interest) were excluded.

Monthly total share return (TSR) ${ }^{(a)}$ :

$$
100 \times\left[\left(\frac{\text { Share price at month end }+\left(\sum_{t=0}^{n-1} \frac{\text { Final dividend per share at time } t}{12} \times \text { share price at time } t\right)}{\text { Share price at the beginning of the month }}\right)-1\right]
$$

The following data were required for risk-adjusted estimation purposes:

Book value of ordinary shares $\left(\text { year }_{t-1}\right)^{(\mathrm{a})}$ :

Ordinary share capital + non-distributable reserves + distributable reserves

Size $\left(\operatorname{year}_{t-1}\right)^{(\text {a) }}$ :

Market capitalisation:

market price per share $\mathrm{x}$ number of ordinary shares issued

Return on the market $^{(\mathrm{b})}$ : FTSE/JSE All Share Index ${ }^{(\mathrm{c})}$

Monthly risk-free rate ${ }^{(b)}$ : Exchange yield on the long-term R186 government bond ${ }^{(d)}$

(a) Data provided by INET BFA

(b) Data provided by the Bureau for Economic Research (BER, 2013)

(c) Previously employed by South African researchers (Ward \& Muller, 2012; Van Rensburg \& Robertson, 2003)

(d) Previously employed by South African researchers (Mlonzi, Kruger \& Nthoesane, 2011)

The application of the estimation models entailed nine steps, as indicated in Table 3. Steps 1, 2 and 9 are applicable to both the CAPM and Fama-French three-factor model, whereas steps 3-8 are only applicable to the latter model. 
Table 3: Application of the CAPM and FAMA-French three-factor model

\begin{tabular}{l|l}
\hline Step 1 & $\begin{array}{l}\text { The monthly risk-adjusted share returns (return on the } i^{\text {th }} \text { share less the risk-free rate) were determined for each of the sample } \\
\text { firms. }\end{array}$ \\
\hline Step 2 & The monthly market risk premiums were calculated. \\
\hline Step 3 & $\begin{array}{l}\text { The small minus big (SMB) size aspect was determined by sorting the firms from large to small, based on their market } \\
\text { capitalisation. In line with Fama and French (1992), firms with the lowest 25\% of market capitalisation were defined as small; the } \\
\text { top 25\% of firms were defined as big. }\end{array}$ \\
\hline Step 4 & $\begin{array}{l}\text { The monthly TSR was determined for each company in the small and big portfolios before calculating the average TSR for the } \\
\text { big and small portfolios on a monthly basis. }\end{array}$ \\
\hline Step 5 & $\begin{array}{l}\text { The average monthly TSR for the big firms was subtracted from the average monthly TSR for the small firms for each of the 108 } \\
\text { months. The monthly differences were the SMB factor. }\end{array}$ \\
\hline Step 6 & $\begin{array}{l}\text { The sample firms' book equity/market equity (BE/ME) ratios were calculated. To determine the high minus low (HML) aspect, } \\
\text { the firms were sorted based on these ratios from high to low. In line with Fama and French (1995), the 30\% of firms with the } \\
\text { highest BE/ME ratio were included in the value portfolio (high), while the bottom 30\% was defined as the growth portfolio (low). }\end{array}$ \\
\hline Step 7 & $\begin{array}{l}\text { The monthly TSR was calculated for each of the firms in the high and low portfolios. The average TSR was then calculated on a } \\
\text { monthly basis for the high and low portfolios respectively. }\end{array}$ \\
\hline Step 8 & $\begin{array}{l}\text { The average TSR of the low portfolio was subtracted from the average TSR for the high portfolio for each of the considered } \\
\text { months. These monthly differences were the HML factor. }\end{array}$ \\
\hline Step 9 & The CAPM and Fama-French three-factor model were used to estimate alpha and betas. \\
\hline
\end{tabular}

Source: Researchers' compilation based on French (2013) and Fama and French (1995)

In this study, attention was given to whether the portfolio consisting of firms with the highest CGSs reported a positive alpha. For this purpose, corporate governance (CG) portfolios were constructed as follows: The entire dataset was considered on a monthly basis. All firms that had a CGS were considered for inclusion in the monthly portfolio (the annual CGS was used for the relevant 12 months). The firms were then ranked according to their CGSs and the $25^{\text {th }}$ and $75^{\text {th }}$ percentiles were calculated. All firms with a CGS within one of these quartiles were included in portfolio $\mathrm{CG}_{1}$ (firms with low CGSs) or portfolio $\mathrm{CG}_{4}$ (companies with high CGSs) respectively. Portfolios $\mathrm{CG}_{2}$ and $\mathrm{CG}_{3}$ respectively consisted of firms within quartiles 2 and 3. Risk-adjusted abnormal returns were estimated for each of these four portfolios on a monthly basis.

\section{Data analysis}

Descriptive statistics were used to summarise the panel dataset. A fixed effects regression model that controls for omitted variables in panel data that are constant over the period of time and vary across the cross-sectional units was employed. The Breusch-Pagan test was used to control for heteroskedastic specification error. Multicollinearity was moderated by the sample size and the fit of the regression model. Acceptable tolerance values (> $0.2-0.3$ ) were determined for the predictors.

\section{Results and discussion}

The CGS descriptive statistics are provided in Table 4.

The annual mean and median CGS increased over the research period. This positive trend could be ascribed to enhanced awareness and knowledge among managers and directors regarding the practical application of the King II guidelines. Although the range decreased over time, some firms had very poor compliance (as reflected by the minimum scores below 30). Figure 2 provides details on the annual mean ROA and ROE profitability ratios.

\section{Table 4: Corporate governance scores}

\begin{tabular}{c|c|c|c|c|c|c}
\hline Years & $\begin{array}{c}\text { Valid } \\
\boldsymbol{n}\end{array}$ & Mean & Median & $\begin{array}{c}\text { Min } \\
\text { (a) }\end{array}$ & $\begin{array}{c}\text { Max } \\
\text { (a) }\end{array}$ & $\begin{array}{c}\text { Standard } \\
\text { deviation } \\
\text { (SD) }\end{array}$ \\
\hline $\mathbf{2 0 0 2}$ & 191 & 39 & 39 & 9 & 67 & 12 \\
\hline $\mathbf{2 0 0 3}$ & 192 & 45 & 47 & 10 & 69 & 12 \\
\hline $\mathbf{2 0 0 4}$ & 166 & 49 & 51 & 9 & 72 & 12 \\
\hline $\mathbf{2 0 0 5}$ & 161 & 51 & 53 & 13 & 71 & 12 \\
\hline $\mathbf{2 0 0 6}$ & 146 & 52 & 54 & 16 & 71 & 12 \\
\hline $\mathbf{2 0 0 7}$ & 141 & 52 & 56 & 16 & 70 & 12 \\
\hline $\mathbf{2 0 0 8}$ & 150 & 55 & 57 & 14 & 72 & 11 \\
\hline $\mathbf{2 0 0 9}$ & 151 & 57 & 59 & 21 & 72 & 10 \\
\hline $\mathbf{2 0 1 0}$ & 141 & 59 & 62 & 27 & 74 & 10 \\
\hline \\
(a) The lowest and highest potential CGS was 0 and 74 respectively
\end{tabular}

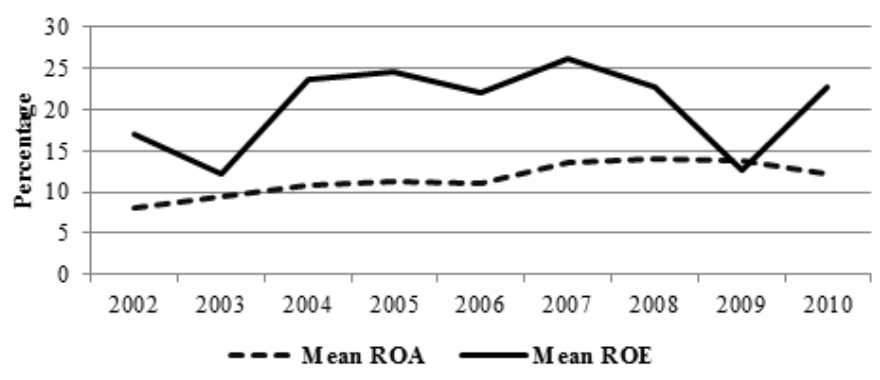

Figure 2: Mean profitability ratios (\%)

Perusal of Figure 2 shows that the annual mean ROE values were higher than the corresponding ROA values (except for 2009), possibly owing to financial leverage. The decreasing trend in the mean ROA and ROE ratios between 2008 and 2009 were not surprising, since South Africa experienced a recession in the first semester of 2009. Figure 3 illustrates the trend in the mean annual EPS (nominal values; cents per share) and TSR (\%) between 2002 and 2010. 


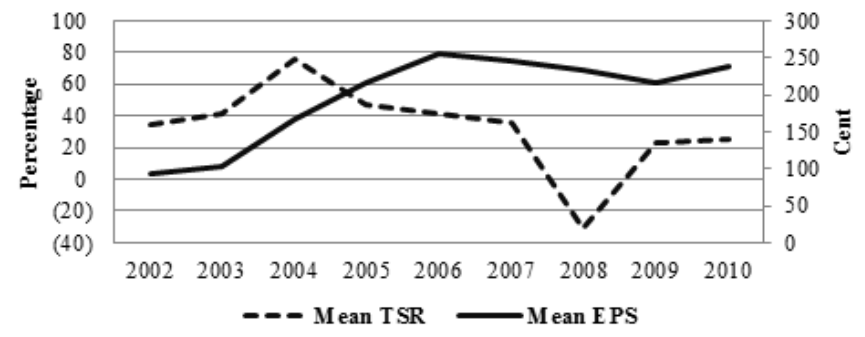

Figure 3: Mean EPS (cent per share) and TSR (\%) values

As shown in Figure 3, the mean EPS ratio increased substantially from 2002 to 2006 . Although steadily increasing EPS values could be ascribed to an improved financial position, inflation and changes in the number of ordinary shares would have a similar impact on this ratio. During 2007-2009, the mean EPS values decreased as a result of the global financial crisis and the local recession. The mean TSR values increased between 2002 and 2004, possibly as a result of South Africa's high economic growth during this period. Thereafter, the mean TSR values gradually decreased in the run-up to the global financial crisis.

Extreme performance values could be ascribed to abnormal profits/losses and small/zero denominators. Winsorising was used to adjust performance outliers. Values in excess of three standard deviations from the mean were classified as outliers and were replaced by a value equal to the mean \pm three standard deviations. Regression analyses (refer to Table 5) were conducted on the winsorised dataset (1 417 annual CGS and performance observations for 227 firms).

In contrast to previous emerging market researchers (refer to Table 1) who reported a positive relationship between corporate governance and ROA and ROE respectively, no significant relationships were observed between the CGS and the investigated profitability ratios in this study.

The significant positive association between CGS and EPS could be interpreted as evidence of a link between sound corporate governance and financial performance. The EPS ratio, however, could be "inflated" by means of share buybacks, without improving actual performance. Share repurchases increased between 1999, when JSE-listed firms were initially allowed to buy back shares, and the late 2000s (Bester, Wesson \& Hamman, 2010). In addition, the CGSs of firms could be artificially improved by window-dressing practices. Shareholders' scepticism about investee firms' corporate governance compliance practices and the reporting thereof might influence their investment decisions. The positive relationship between EPS and CGS should thus be interpreted with caution.

The negative association observed between CGS and TSR could appear unexpected, given that a well-functioning capital market requires a robust corporate governance framework that rewards shareholders for their monitoring of managers' actions (Organisation for Economic Co-operation and Development, 2012). Officer (2011), however, argued that firms with weak corporate governance are more likely to pay out cash dividends. Positive share price reactions to these dividend announcements would contribute towards an increase in TSR, providing a possible explanation for high TSRs reported by some badly governed firms.

Table 5: Regression analysis results for CGS and EPS, ROA, ROE and TSR

\begin{tabular}{|c|c|c|c|c|}
\hline \multicolumn{2}{|c|}{$\begin{array}{l}\text { Preferred } \\
\text { model }\end{array}$} & $\begin{array}{c}\text { Test for } \\
\text { fixed effects } \\
(F)\end{array}$ & $\begin{array}{c}\text { Hausman test } \\
\text { for random } \\
\text { effects }(F)\end{array}$ & $\begin{array}{l}\text { Fit of } \\
\text { the } \\
\text { model } \\
F(d f)\end{array}$ \\
\hline \multicolumn{2}{|c|}{ Fixed effects } & $18.46^{* *}$ & $2065.78^{* *}$ & $\begin{array}{c}18.62^{* * *} \\
(4, \\
1099)\end{array}$ \\
\hline \multicolumn{2}{|c|}{$\begin{array}{l}\text { Regression } \\
\text { coefficient }\end{array}$} & $\begin{array}{c}\text { Standard } \\
\text { error }\end{array}$ & $t$-value & $\operatorname{Pr}>|t|$ \\
\hline EPS & $0.014^{* *}$ & 0.002 & $7.323^{* *}$ & 0.000 \\
\hline ROA & -0.024 & 0.069 & -0.343 & 0.731 \\
\hline ROE & 0.004 & 0.008 & 0.488 & 0.625 \\
\hline TSR & $-1.933^{* *}$ & 0.545 & $-3.547^{* *}$ & 0.000 \\
\hline \multicolumn{3}{|c|}{$\begin{array}{l}\text { Breusch-Pagan test for } \\
\text { heteroskedasticity }(B P)\end{array}$} & \multicolumn{2}{|c|}{$\begin{array}{l}t \text {-value adjusted for } \\
\text { heteroskedasticity }\end{array}$} \\
\hline EPS & \multirow{4}{*}{\multicolumn{2}{|c|}{$445.04^{* *}$}} & \multicolumn{2}{|c|}{$4.770^{* * *}$} \\
\hline ROA & & & \multicolumn{2}{|c|}{-0.279} \\
\hline ROE & & & \multicolumn{2}{|c|}{0.406} \\
\hline TSR & & & \multicolumn{2}{|c|}{$-3.741^{\text {** }}$} \\
\hline \multicolumn{3}{|c|}{ Significant at the $1 \%$ level } & * Significi & at the $5 \%$ le \\
\hline
\end{tabular}

An alternative explanation for the negative relationship is related to shareholders' perceptions of corporate governance. The implementation of corporate governance mechanisms can be costly in terms of time and money allocated to such initiatives. If local investors regard (costly) initiatives as unnecessary, the share market might penalise firms with high CGSs. Possible mistrust in the accuracy of reporting practices could also result in low share prices and hence low TSRs for some of the considered firms with high CGSs.

When considering the negative association between CGS and TSR, it should also be taken into account that while the mean CGS gradually increased over the research period, the mean TSR fluctuated. Negative TSR values were furthermore reported during the height of the 2007/2008 global financial crisis. These contrasting trends make it difficult to determine whether the observed negative relationship was due to the market's lack of appreciation of corporate governance (or even penalisation for such initiatives), or rather due to the changes in the these two variables over the research period.

Regression analyses were also conducted where all variables were lagged for one year, and by considering inflationadjusted EPS (to account for possible inflation-related distortion). The results remained consistent. Given that none of the measures reported so far were adjusted for risk, riskadjusted abnormal returns (as denoted by Jensen's alpha) were estimated for four corporate governance portfolios by employing the CAPM and Fama-French three-factor model. The results of these estimations are provided in Tables 6 and 7. 
Table 6: CAPM estimation results

\begin{tabular}{l|c|c|c|c|c|c|c}
\hline \multicolumn{1}{c|}{ CG portfolio } & $\begin{array}{c}\text { Mean } \\
\text { CGS }\end{array}$ & $\begin{array}{c}\text { Mean } \\
\text { TSR }\end{array}$ & Estimate of $\boldsymbol{\alpha}$ & $\begin{array}{c}\text { Estimate of } \\
\boldsymbol{\beta}\end{array}$ & $\boldsymbol{R}$-squared & $\begin{array}{c}\text { Standard } \\
\text { error }\end{array}$ & \begin{tabular}{c}
$\boldsymbol{F}$-value \\
\hline 1: very low CGSs
\end{tabular} \\
\hline 2: low to average CGSs & 45 & $4.140 \%$ & $\mathbf{1 . 7 5 7 \%}^{* *}$ & $\mathbf{0 . 5 8 6}^{* *}$ & 0.234 & 0.047 & $\mathbf{3 2 . 3 5 6}^{* *}$ \\
\hline 3: moderate CGSs & 56 & $0.385 \%$ & $0.606 \%$ & $\mathbf{0 . 4 8 6}^{* *}$ & 0.087 & 0.070 & $\mathbf{1 0 . 1 4 3}^{* *}$ \\
\hline 4: high CGSs & 64 & $2.463 \%$ & $0.654 \%$ & $\mathbf{0 . 7 5 9}^{* *}$ & 0.360 & 0.045 & $\mathbf{5 9 . 6 9 3}^{* *}$ \\
\hline ** Significant at the 1\% level & $\mathbf{1 . 2 5 0 \%}^{* *}$ & $\mathbf{0 . 5 8 0}^{* *}$ & 0.281 & 0.041 & $\mathbf{4 1 . 3 7 4}^{* *}$ \\
\hline
\end{tabular}

$$
\text { ** Significant at the } 1 \% \text { level }
$$

Degrees of freedom: $1 ; 106$; the quality of fit of all models was significant.

Regression equation based on monthly data $(t)$ for each of the four CG portfolios ( $p$ ) (Lee, Lee \& Lee, 2009):

$$
\begin{aligned}
& \left(\mathrm{R}_{p t}-\mathrm{R}_{f t}\right)=\alpha_{p}+\beta_{p}\left(\mathrm{R}_{m t}-\mathrm{R}_{f t}\right)+\epsilon_{p} \\
& \text { Where: } \quad \mathrm{R}_{p t} \text { is the return on portfolio } p \text { during month } t \\
& \mathrm{R}_{m t} \text { is the monthly return on the FTSE/JSE All Share Index } \\
& \beta_{p} \text { is the systematic risk of portfolio } p
\end{aligned}
$$

The alphas of both portfolios $\mathrm{CG}_{1}$ and $\mathrm{CG}_{4}$ were positive and significant. The risk-adjusted abnormal return of portfolio $\mathrm{CG}_{1}$ is considerably lower (approximately 2.4\%) than its TSR. The mean TSR of portfolio $\mathrm{CG}_{1}$ hence appear to be achieved at a high level of risk. In contrast, the mean TSR and alpha of portfolio $\mathrm{CG}_{4}$ only differs by approximately 1.2 per cent, a sign that this portfolio exposed investors to relatively less risk than portfolio $\mathrm{CG}_{1}$. Portfolios $\mathrm{CG}_{1}$ and $\mathrm{CG}_{4}$ had similar beta values, reflecting some unexpected results. Previous researchers (e.g. Strugnell, Gilbert \& Kruger, 2011; Van Rensburg \& Robertson, 2003) reported that the beta estimates of South African firms could be inversely related to their returns. The interpretation of beta values should thus be conducted with care within the South African corporate context (Erasmus, 2013).

As shown in Table 7, investors, who invested in the considered firms with the highest CGSs during the research period, earned a significant positive risk-adjusted abnormal return. Only one size-related beta was significant. A possible explanation is that the firms' sizes were already accounted

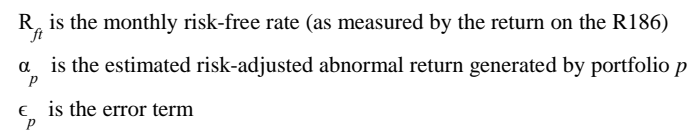

for, since the FTSE/JSE All Share Index is weighted according to market capitalisation. The negative value/growth betas of portfolios $\mathrm{CG}_{3}$ and $\mathrm{CG}_{4}$ indicate that growth shares have outperformed value shares. Growth shares typically have above-average earnings growth. Such firms prefer to reinvest earnings to fund growth opportunities rather than to pay out dividends (Besley \& Brigham, 2008). Growth firms could thus have more funds available to invest in corporate governance initiatives than their counterparts that pay out dividends.

Monthly equally-weighted portfolio returns were also determined, based on the average monthly share returns of the considered firms. When this alternative proxy for the market return was employed, the CAPM estimation indicated a positive, but not significant alpha for Portfolio $\mathrm{CG}_{4}$, while a significant positive alpha was observed for portfolio $\mathrm{CG}_{1}$.

\begin{tabular}{|c|c|c|c|c|c|c|c|c|c|}
\hline CG portfolio & $\begin{array}{c}\text { Mean } \\
\text { CGS }\end{array}$ & $\begin{array}{l}\text { Mean } \\
\text { TSR }\end{array}$ & $\begin{array}{l}\text { Estimate } \\
\text { of } \alpha\end{array}$ & $\begin{array}{c}\text { Estimate } \\
\text { of } \beta_{1}\end{array}$ & $\begin{array}{c}\text { Estimate } \\
\text { of } \beta_{2}\end{array}$ & $\begin{array}{c}\text { Estimate of } \\
\beta_{3}\end{array}$ & $\begin{array}{l}\text { Adjusted } R- \\
\text { squared }\end{array}$ & $\begin{array}{c}\text { Standard } \\
\text { error }\end{array}$ & $F$-value \\
\hline $\begin{array}{l}\text { 1: very low } \\
\text { CGSs }\end{array}$ & 35 & $4.140 \%$ & $1.061 \%$ ** & $0.593^{* *}$ & -0.039 & $0.495^{* *}$ & 0.448 & 0.040 & $29.952^{* *}$ \\
\hline $\begin{array}{l}\text { 2: low to } \\
\text { average } \\
\text { CGSs }\end{array}$ & 49 & $0.385 \%$ & $1.065 \% *$ & $0.609^{* *}$ & $0.712^{* *}$ & -0.102 & 0.478 & 0.053 & 33.677 * \\
\hline $\begin{array}{l}\text { 3: moderate } \\
\text { CGSs }\end{array}$ & 56 & $1.463 \%$ & $0.993 \% *$ & $0.768^{* *}$ & 0.084 & $-0.220^{* * *}$ & 0.385 & 0.044 & $23.315^{* *}$ \\
\hline $\begin{array}{l}\text { 4: high } \\
\text { CGSs }\end{array}$ & 64 & $2.450 \%$ & $1.595 \% \%^{* *}$ & $0.572^{* *}$ & -0.006 & $-0.254^{* *}$ & 0.342 & 0.039 & $19.499^{* *}$ \\
\hline
\end{tabular}
The Fama-French three-factor estimation indicated a significant positive alpha for portfolio $\mathrm{CG}_{4}$, while an insignificant negative alpha was reported for portfolio $\mathrm{CG}_{1}$.

Table 7: Fama-French three-factor model estimation results

Degrees of freedom: $3 ; 104$. The quality of fit of all models was significant.

Regression equation based on monthly data $(t)$ for each of the four CG portfolios ( $p$ ) (Fama \& French, 1992):
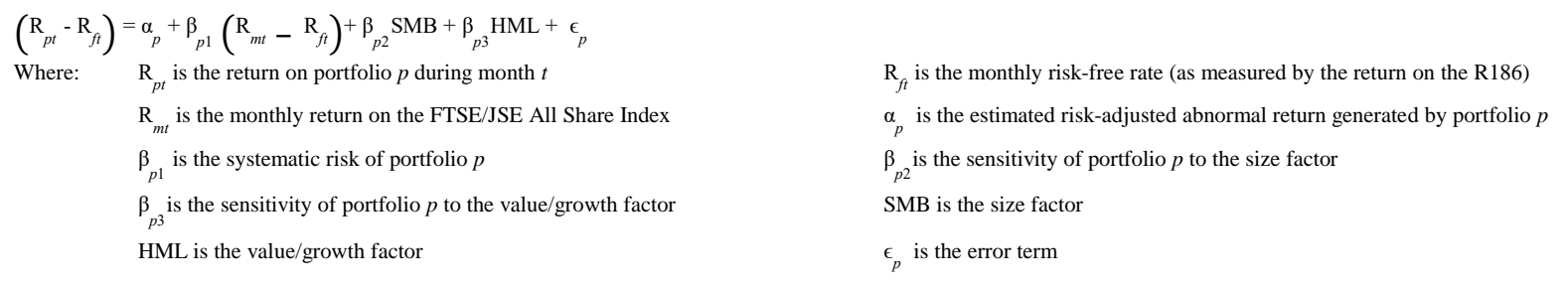
Based on the reported results, both null hypotheses were rejected. The results indicated both positive (significant EPS and insignificant ROE) and negative (insignificant ROA and significant TSR) relationships between financial performance and corporate governance. Positive risk-adjusted abnormal returns were reported for the portfolio comprising the companies with the highest corporate governance scores by employing both the CAPM and the Fama-French three-factor model.

\section{Conclusions}

In contrast to previous emerging market researchers who predominantly focused on board-related variables, comprehensive CGSs reflecting both disclosure and acceptability criteria were compiled for this study. A combination of different performance measures employed in previous studies was furthermore used to distinguish between different aspects of financial performance.

A significant positive relationship was observed between CGS and the accounting-based EPS ratio. It should, however, be noted that management has a degree of control over both EPS and the level of corporate governance compliance. The observed positive association might hence partially be attributed to the actions of managers. A statistically significant negative relationship was noted between CGS and the market-based TSR measure. This finding might be attributed to shareholders' scepticism regarding the true nature of some firms' compliance practices. A combination of high compliance costs and perceived window-dressing activities might have affected the market's perception of corporate governance compliance. The negative association might hence be ascribed to market perceptions related to "unnecessary, costly corporate governance expenses".

Since the mean TSRs were negatively affected during the crisis period while the CGSs continued to improve, it was difficult to infer whether the observed association was due to negative perceptions, or rather due to changes in the variables over time. Given Schopenhauer's statement that a concept (corporate governance) will first be ridiculed and resisted, before it will be accepted, the negative association might indicate that corporate governance is, to a certain extent, not yet properly understood or appreciated by some local corporate role-players.

To assess the potential risk reducing benefits of sound corporate governance compliance, the CAPM and FamaFrench three-factor models were employed to estimate riskadjusted abnormal share returns for four corporate governance-sorted portfolios. Both the CAPM and FamaFrench three-factor model estimations indicated significant positive alphas for the portfolio containing firms with the highest CGSs. Although the portfolio of firms with the lowest CGSs also reported a significant positive alpha, there was a marked decline from the TSRs reported for these firms. These results highlight that the high TSRs reported by low CGS firms were achieved at the expense of exposing shareholders to a high degree of risk.

\section{Limitations and recommendations}

Recommendations are offered to various stakeholders, including shareholders, managers, directors, the media and academics. More shareholders should come on board by realising and appreciating the possible benefits (as reflected by risk-adjusted returns) that are associated with acceptable corporate governance practices. Furthermore, the perceived business case for corporate governance might encourage the managers and directors of the considered companies to improve their corporate governance practices in future.

Enhanced education and training is required to further improve managers' and directors' understanding of corporate governance. In addition, the local media can encourage corporate governance discussions by reporting on corporate governance accomplishments and concerns. A combination of education, training and public dialogue could change the mind-sets of corporate role players. In future, shareholders, managers and directors might then regard sound corporate governance compliance as essential instead of being a mere obligation.

Recommendations for future research are based on two identified limitations. Firstly, companies that were listed in the basic materials, oil and gas and financials industries were excluded from the sample, due to their financial reporting and extent of regulation that differ from the considered industries. Future researchers might consider the relationship between the financial performance and corporate governance practices of such companies. Secondly, the researchers were interested in the recommendations of the King II Report. Future studies can employ the guidelines of the King III Report (which focuses on integrated reporting) to compile scores based on JSE-listed firms' environmental, social and corporate governance aspects. The relationship between such scores and the considered firms' financial performance can then be examined.

\section{Acknowledgements}

The authors would like to thank the Centre for Corporate Governance in Africa at the University of Stellenbosch Business School for permission to use a refined version of their PIC Corporate Governance Rating Matrix. The authors also extend their gratitude to Professor Martin Kidd for his assistance with the statistical analysis, the reviewers for their valuable feedback and the National Research Foundation for financial support.

\section{References}

Abdo, A. \& Fisher, G. 2007. 'The impact of reported corporate governance disclosure on the financial performance of companies listed on the JSE', Investment Analysts Journal, 36(66): 43-56.

Alhaji, I.A., Yusoff, W.F. \& Alkali, M. 2012. Corporate governance and firm performance: A comparative analysis of two sectors of Malaysian listed companies. Paper presented at the $2^{\text {nd }}$ International Conference on Management, 11-12 June, Langkawi Kedah, Malaysia. 
Besley, S. \& Brigham, E.F. 2008. Essentials of managerial finance. 14th Edition. Mason: Thomson South-Western.

Bester, P.G., Wesson, N. \& Hamman, W.D. 2010. 'Share buy-backs for a selection of JSE listed companies: An exploratory study', South African Journal of Business Management, 41(4): 47-58.

Bureau for Economic Research (BER). 2013. Forecasts and data. [online] www.ber.ac.za/forecasts/2010.aspx.

Chi, L-C. 2009. 'Do transparency and disclosure predict firm performance? Evidence from the Taiwan market', Expert Systems with Applications, 36(8): 11198-11203.

Committee on the Financial Aspects of Corporate Governance. 1992. Report of the committee on the financial aspects of corporate governance (Cadbury Report). London: Gee.

Department: National Treasury Republic of South Africa. 2011. Pension Funds Act, 1956: Amendment of regulation 28 of the regulations made under section 36. [online] www.libertycorporate.co.za/legal-matters/Documents/reg-28 /regulation-28-act.pdf.

Du Plessis, J.J., Hargovan, A. \& Bagaric, M. 2011. Principles of contemporary corporate governance. 2nd Edition. Port Melbourne: Cambridge University Press.

Dybvig, P.H. \& Warachka, M. 2010. Tobin's $Q$ does not measure performance: Theory, empirics and alternative measures. [online] papers.ssrn.com/sol3/ papers.cfm?abstract_id=1562444.

Ehikioya, B.I. 2009. 'Corporate governance structure and firm performance in developing economies: Evidence from Nigeria', Corporate Governance: The International Journal of Business in Society, 9(3): 231-243.

Erasmus, P.D. 2013. 'The influence of dividend yield and dividend stability on share returns: Implications for dividend policy formulation', Journal of Economic and Financial Sciences, 6(1): 1331.

Fallatah, Y. \& Dickins, D. 2012. 'Corporate governance and firm performance and value in Saudi Arabia', African Journal of Business Management, 6(36): 10025-10034.

Fama, E.F. \& French, K.R. 1992. 'The cross-section of expected stock returns', The Journal of Finance, 47(2): 427-465.

Fama, E.F. \& French, K.R. 1995. 'Size and book-to-market factors in earnings and returns', The Journal of Finance, 50(1): 131-155.

French, K.R. 2013. Current research returns. [online] mba.tuck.dartmouth.edu/pages/faculty/ken.french/data_library.html

Global Sustainable Investment Alliance. 2012. Global sustainable investment review. [online] gsiareview2012.gsi-alliance.org/index. $\mathrm{html} \# / 1 /$.

Grandori, A. 2004. Corporate governance and firm organization: Microfoundations and structural forms. Oxford: Oxford University Press.

Haniffa, R. \& Hudaib, M. 2006. 'Corporate governance structure and performance of Malaysian listed companies', Journal of Business Finance and Accounting, 33 (7/8): 1034-1062.
Hassan, M.K. \& Halbouni, S.S. 2013. 'Corporate governance, economic turbulence and financial performance of UAE listed firms', Studies in Economics and Finance, 30(2): 118-138.

Heath, A. 2014. 'The chatter: Top talent can wear two hats in era of many rules', Business Day Live, 10 August. [online] www.bdlive.co.za/businesstimes/2014/08/10/the-chatter-top-talentcan-wear-two-hats-in-era-of-many-rules.

Hörnmark, P. 2015. Responsible investment: Should investors incorporate ESG principles when investing in emerging markets. Master's thesis. Jönköping International Business School, Jönköping, Sweden.

Imam, M.O. \& Malik, M. 2007. 'Firm performance and corporate governance through ownership structure: Evidence from Bangladesh stock market', International Review of Business Research Papers, 3(4): 88-110.

Institute of Directors in Southern Africa (IoDSA). 2009. King Report on Corporate Governance for South Africa - 2009. Johannesburg: IoDSA.

Institute of Directors in Southern Africa (IoDSA). 2011. Code for Responsible Investing in SA (CRISA). [online] www.iodsa.co.za/?page=CRISACode.

Investment Leaders Group. 2014. The value of responsible investment: The moral, financial and economic case for action. [online] www.cisl.cam.ac.uk/publications/publication-pdfs/ilg-thevalue-of-responsible-investment.pdf.

Islam, J., Sathye, M. \& Hu, H. 2015. 'Examining the relationship between corporate governance and bank performance in Bangladesh', South African Journal of Business Management, 46(4): 43-51.

Joh, S.W. 2003. 'Corporate governance and firm profitability: Evidence from Korea before the economic crisis', Journal of Financial Economics, 68(2): 287-322.

Johannesburg Stock Exchange (JSE). 2005. JSE Listing Requirements. Durban: LexisNexis Butterworths.

Kajola, S.O. 2008. 'Corporate governance and firm performance: The case of Nigerian listed firms', European Journal of Economics, Finance and Administrative Sciences, 14(14): 16-28.

Klapper, L.F. \& Love, I. 2004. 'Corporate governance, investor protection, and performance in emerging markets', Journal of Corporate Finance, 10(5): 703-728.

Kyereboah-Coleman, A. 2007. Relationship between corporate governance and firm performance: An African perspective. Unpublished $\mathrm{PhD}$ dissertation, Stellenbosch University, Stellenbosch.

Lee, A.C., Lee, J.C. \& Lee, C-F. 2009. Financial analysis, planning and forecasting: Theory and application. 2nd Edition. Singapore: World Scientific.

Mlonzi, V.F., Kruger, J. \& Nthoesane, M.G. 2011. 'Share price reaction to earnings announcement on the JSE-AltX: A test for market efficiency', Southern African Business Review, 15(3): 142166. 
Mollah, S., Al Farooque, O. \& Karim, W. 2012. 'Ownership structure, corporate governance and firm performance: Evidence from an African emerging market', Studies in Economics and Finance, 29(4): 301-319.

Morey, M., Gottesman, A., Baker, E. \& Godridge, B. 2009. 'Does better corporate governance result in higher valuations in emerging markets? Another examination using a new data set', Journal of Banking and Finance, 33(2): 254-262.

Mulsow, R. 2011. The relationship between project-portfolio success and multi-dimensional business success: An analysis based on an empirical multi-project management study. Norderstedt: GrinVerlag.

Ntim, C.G., Opong, K.K. \& Danbolt, J. 2012. 'The relative value relevance of shareholder versus stakeholder corporate governance disclosure policy reforms in South Africa', Corporate Governance: An International Review, 20(1): 84-105.

Officer, M.S. 2011. 'Overinvestment, corporate governance, and dividend initiations', Journal of Corporate Finance, 17(3): 710-724.

Organisation for Economic Co-operation and Development. 2012. Corporate governance, value creation and growth. [online] www.oecd.org/corporate/ca/corporategovernanceprinciples/ 50242938.pdf.

Othman, H.B. 2012. 'The effect of board structure and process disclosure on corporate performance in the emerging African markets', Managerial Auditing Journal, 27(2): 156-174.

Pamburai, H.H., Chamisa, E., Abdulla, C. \& Smith, C. 2015. 'An analysis of corporate governance and company performance: A South African perspective', South African Journal of Accounting Research, 29(2): 115-131.

Ramdani, D. \& Van Witteloostuijn, A. 2010. 'The impact of board independence and CEO duality on firm performance: A quantile regression analysis for Indonesia, Malaysia, South Korea and Thailand', British Journal of Management, 21(3): 607-626.

Shleifer, A. \& Vishny, R.W. 1997. 'A survey of corporate governance', The Journal of Finance, 52(2): 737-783.

Strugnell, D., Gilbert, E. \& Kruger, R. 2011. 'Beta, size and value effects on the JSE, 1994-2007', Investment Analysts Journal, 40(74): 1-17.

Van der Ahee, G. \& Schulschenk, J. 2013. The state of responsible investment in South Africa. [online] www.ey.com/Publication/ vwLUAssets/The_State_of_Responsible_Investment_in_South_Af rica/\$FILE/Responsible\%20Investment\%20Study\%202013.pdf.

Van Rensburg, P. \& Robertson, M. 2003. 'Size, price-to-earnings and beta on the JSE Securities Exchange', Investment Analysts Journal, 32(58): 7-16.

Velnampy, T. 2013. 'Corporate governance and firm performance: A study of Sri Lankan manufacturing companies', Journal of Economics and Sustainable Development, 4(3): 228-235.

Viviers, S., Bosch, J.K., Smit, E.v.d.M. \& Buijs, A. 2009. 'Responsible investing in South Africa', Investment Analysts Journal, 38(69): 3-16.
Ward, M. \& Muller, C. 2012. 'Empirical testing of the CAPM on the JSE', Investment Analysts Journal, 41(76): 1-12. 